\title{
Los orígenes de la Universidad en España: El Studium Generale de Palencia (siglos XII y XIII)
}

\author{
Javier Divar \\ Universidad de Deusto
}

Recibido: $\quad 14.02 .08$

Aceptado: 07.03 .08

Sumario: I. Los precedentes históricos,- -II. El reconocimiento oficial del Studium Generale de Palencia,_-III. Palencia, Universidad de Santos.

En reconocimiento a la ciudad de Palencia, antigua capital de los Vacceos, pueblo que estableció un sistema económico comunitario precooperativo, 600 años a. C., y primera ciudad de los viejos Reinos Hispánicos en albergar un Centro de Estudios Superiores.

\section{Los precedentes históricos}

La vieja capital de Pallantia, ya citada como una de las poblaciones más notables de Hispania por Plinio el Viejo, fue un primitivo asentamiento de los Vacceos, pueblo establecido en la Meseta Norte de Iberia al menos seiscientos años antes de Cristo, destacado por su sistema productivo cerealista, en régimen comunitario precooperativo. Fueron sometidos por los romanos en el siglo ॥ a.C., los cuales introdujeron la vid en la zona (orígen de la afamada comarca vitivinícola del Duero), estableciendo sus bases operativas y de aprovisionamiento para la toma de la cornisa atlántica, en lo que ha dado en llamarse «Las Guerras Cántabras», cuyos horrores fueron relatados por Estrabón, que extendió por todo el Imperio Romano la noticia sobre la fiereza y la naturaleza indómita de los cántabros.

La Palencia cristianizada tras la romanización fue la base para la conversión de las paganas tribus cántabras. Santo Toribio de Palencia evangelizó la zona occidental de Cantabria (en la zona oriental San Millán y sus compañeros desde La Rioja), cuestión a la que hace referencia Joaquín González Echegaray en su "Cantabria a través de su Historia», donde dice textualmente: "La zona más intensamente evangelizada 
por el grupo de Santo Toribio fue la Liébana, donde por entonces nació el cenobio de San Martín, más tarde monasterio, que con el tiempo recibiría el nombre de su fundador Santo Toribio. El Obispo Montano alaba la labor de Toribio en su lucha contra el paganismo de los cántabros y San Ildefonso de Toledo en su «Vida de los Varones Ilustres» se refiere a Santo Toribio de Palencia y a su misión para destruir el culto a los ídolos en la región de Cantabria» 1.

La importancia urbana y cristiana de Palencia explica que para el siglo III se cree ya su sede episcopal, brillando en el periodo de la monarquía visigótica. Es a mediados del siglo vII cuando se levantó un templo visigótico sobre los restos de una anterior fortaleza romana cercana al río Carrión, templo sobre el que posteriormente se levantará la extraordinaria Catedral de Palencia, conjunto constructivo cuya fábrica se prolongó durante quinientos años.

Sobre el anterior templo visigótico del siglo vII, el Obispo Don Ponce, establecido en la sede en el año 1034 por el Rey de Navarra, Sancho el Mayor (conjuntamente con el Rey de León, Bermudo III), y a instancias del rey navarro, comenzó la obra de la Cripta de San Antolín, compuesta por dos secciones, visigótica la primera y prerrománica la segunda, paralelamente al eje de la Catedral actual, bajo el Coro, con algo más de 27 metros de longitud.

La advocación a San Antolín, patrono de los cazadores, nacido en el siglo III en la Galia Narbonense y ordenado sacerdote en Palermo, y que vuelto a su patria sufrió persecución por su fe, muriendo en el martirio, se debe a que el rey navarro le tenía gran devoción y en un trance de caza por el que sufrió una parálisis hizo promesa al santo de erigirle un templo si sanaba. Por ello parece ser que ordenó el traslado de los restos del santo a la cripta palentina.

Pero fue en el siglo XII, siendo Obispo de Palencia Raimundo II cuando se decidió levantar una Catedral sobre la Cripta de San Antolín, para engrandecer la sede episcopal palentina, que ya albergaba una reconocida Escuela de Estudios Eclesiásticos, orígen de su Estudio General.

En 1218, siendo Obispo D.Tello Téllez Meneses, que en 1208 había reconocido oficialmente el Studium Generale (fecha citada por algunos como la de la fundación oficial universitaria palentina), se concluyó la Catedral románica, de vida efímera, puesto que el $1 .^{\circ}$ de junio de 1321 se bendijo la colocación de la primera piedra de la Catedral gótica, co-

1 J. González Echegaray. «Cantabria a través de su Historia». Edición de la Diputación Provincial. Santander, 1977, pág.172. 
menzándose por la construcción de siete capillas absidales en la cabecera. La bóveda se cerró en el siglo XV, en el episcopado de Don Sancho de Rojas, y la torre al finalizar el siglo, en el episcopado de Don Gutierre IV, siendo maestro de obras el burgalés Gómez Díaz. El crucero se culminó en 1497, siendo Obispo Fray Alonso de Burgos.

La construcción de la Catedral culminó en 1516, siendo Obispo Don Juan Fernández de Velasco, con el maestro de obras Pascual de Jaén.

\section{El reconocimiento oficial del Studium Generale de Palencia}

Al uso original de los centros de estudios superiores persas, y conforme al precedente cercano islámico (la Córdoba califal en el siglo VIII , como caso más destacado de Europa), la civilización cristiana comenzó a reconocer centros de estudios superiores de excelencia, caso de Bolonia en el año 1088, Oxford en el de 1096, París en 1150, Módena en 1175, y a comienzos del siglo XIII, Cambridge, sobre el año de 1208.

Aunque su fundación es del siglo XII (en el año 1184 estudiaba en el Estudio General palentino Santo Domingo de Guzmán, que sobre el año 1194 fue designado Regente de la Cátedra de Sagradas Escrituras), el reconocimiento oficial de la Universidad de Palencia se produce en los años de 1208 (el eclesiástico) y 1212 (el real).

El reconocimiento eclesiástico como centro de estudios superiores del Studium Generale de Palencia se produce por Don Tello Téllez de Meneses, que fue Obispo de la ciudad de 1208 a 1247. Como segundón de una familia noble oriunda de Portugal, Don Tello entró en la carrera eclesiástica, recibiendo la importante sede episcopal de Palencia, que en aquel entonces se extendía desde la actual provincia de Burgos hasta las puertas de la ciudad de Valladolid (incluída Cabezón de Pisuerga). A principios del siglo XII ya se habían celebrado dos Concilios en la sede palentina, con la asistencia de los reyes de Castilla (los de 1113 y 1124).

Don Tello participó con sus propias tropas en la batalla de Las Navas de Tolosa (1212), acompañando al rey de Castilla Alfonso VIII, al que se unieron el rey de Aragón, Pedro II el Católico, y el de Navarra, Sancho VII el Fuerte, a más de las Ordenes Militares. Como quiera que el Papa Inocencio III había decretado como Cruzada la guerra contra los almohades, además del Obispo de Palencia acudieron a la lucha los de Tarazona, Toledo, Sigüenza, Osma, Avila y Plasencia. Todos juntos derrotaron al ejército del califa Miramamolín en Las Navas, Jaén, el 16 de julio de 1212, abriendo el camino para la reconquista de Al-Andalus. 
El reconocimiento real de la Universidad de Palencia se produjo por el rey de Castilla Alfonso VIII en el mismo año de 1212. Alfonso VIII el Noble era hijo de Sancho III y de Blanca de Navarra. Fue coronado como rey de Castilla en el año de 1158. Como hitos principales de su reinado merecen citarse la reconquista de Cuenca, el 21 de septiembre de 1177, festividad de San Mateo; la fundación de Plasencia (1186) y la recuperación para Castilla de buena parte de La Rioja, que estaba en manos navarras. A más de, y por ello es también conocido como «el de Las Navas», su victoria en la famosa batalla de Las Navas, en Jaén, como queda indicado.

El fomento cultural de su reinado procedió en buena parte de su esposa Doña Leonor, hija de Enrique II de Inglaterra y de Leonor de Aquitania, y hermana de Ricardo Corazón de León. Tuvieron catorce hijos, entre ellos al Infante Don Enrique, sucesor en la corona de Castilla desde 1214, año en que falleció su padre, Alfonso VIII. Pero el reinado de Enrique fue efímero, pues falleció en Palencia en 1217, sucediéndole su hermana Doña Berenguela, reina de Castilla desde ese año y consorte de León por su matrimonio con Alfonso IX de León. La política matrimonial de la dinastía se amplió con otros hijos de Alfonso VIII de Castilla y Doña Leonor: Doña Urraca, reina consorte de Portugal por su matrimonio con Alfonso II de Portugal; Doña Blanca, nacida en Palencia en 1188, reina consorte de Francia por su matrimonio con Luis VIII de Francia; y finalmente, Doña Leonor, reina consorte de Aragón por su matrimonio con Jaime I de Aragón.

Alfonso VIII y su esposa Doña Leonor están enterrados juntos en el extraordinario Monasterio de Las Huelgas, en Burgos, en el Panteón de los Reyes de Castilla.

Antes de sus reconocimientos oficiales el Studium o Universidad de Palencia, conforme al uso bajomedieval, ya dividía sus enseñanzas en los Ciclos del Trivium (Gramática, Retórica y Lógica) y del Quadrivium (Aritmética, Geometría, Astronomía y Música), todo ello bajo las enseñanzas teológicas, por lo que sus licenciados lo eran en Teología y Artes, al decir de la época.

Además, Palencia se destacó por los estudios complementarios jurídicos, al modo de Bolonia (de donde procedieron varios de sus maestros regentes o catedráticos), como prueba el hallazgo de lecciones impartidas por el maestro Ugolino de Sesso, fechadas en 1196, que fue un eminente procesalista², glosado por J. San Martín en su obra «La

\footnotetext{
2 Autor de los «Tractatus de Appelatione», «Tractatus de Recusatione Judicum»y «Tractatus de Testibus».
} 
antigua Universidad de Palencia» ${ }^{3}$. También se utilizaron los textos de los maestros teólogos Odo de Chéritón, que era master por París, autor de unas «Parabolae» (traducidas al castellano como «Libro de los gatos»), en las que utilizaba a los animales como vehículos para los ejemplos morales, en las que incluye citas de España (parece que impartió clases en Palencia y Salamanca) ${ }^{4}$; Lanfranco, que fue arzobispo de Canterbury (1070-1089), consejero principal de Guillermo I el Conquistador, Primado de Inglaterra y abad del monasterio benedictino de Bec (cerca de Ruan), donde fundó una prestigiosa Escuela de Teología que adquirió fama en toda Europa; del maestro Fornelino, uno de los teólogos más reputados y citados de la época; y, finalmente, de Pedro Lombardo, cuyas obras fueron libro de texto de Teología en toda Europa, complementadas por las refutaciones de Guillermo de Ockham.

Pero al morir Alfonso VIII de Castilla en 1214, Palencia pierde el favor real y al poco Alfonso IX de León traslada la Universidad a Salamanca, en 12185. Poco después, en 1228, el Concilio de Valladolid acordó restaurar el Studium Generale de Palencia, pero volvió a desaparecer ante la competencia de Salamanca y Valladolid, ésta última como ciudad emergente y muy cercana a Palencia, desde donde parece ser que se trasladó el nuevo Estudio General palentino a mediados del siglo XII, fundándose la Universidad de Valladolid en el último cuarto del siglo XIII.

Sin embargo el precedente palentino sirve de ejemplo a las nuevas constituciones universitarias ibéricas, caso de la Universidad antigua de Sevilla, fundada sobre el año 1254 y desaparecida en 1270; la de Lérida, fundada por Jaime II de Aragón hacia 1279; la de Lisboa (hacia 1288), aunque el rey Dionís de Portugal la trasladó a Coimbra en 1308; y después las de Huesca (1354), Girona (1446), Barcelona (1450), Zaragoza (1474), Palma de Mallorca (1483), Sigüenza (1489), Alcalá de Henares (1499) y Valencia $(1500)^{6}$.

3 J. SAN MARTín. «La antigua Universidad de Palencia». Madrid, 1942.

${ }^{4}$ Estudiado por Enzo Franchini, en la Revista de Poética Medieval, n. ${ }^{\circ}$ 2, 1998. Universidad de Alcalá de Henares.

${ }^{5}$ C.M. Ajo González de Repariegos y Sáinz de ZúñIGa. «Historia de las Universidades Hispánicas». Madrid, 1957.

${ }^{6}$ Hilde De RIDDER-SyMOENS. «Historia de la Universidad en Europa».UPV. Bilbao, 1994. 


\section{Palencia, Universidad de Santos}

A pesar de su corta vida el Studium Generale de Palencia destaca históricamente por ser el centro de estudios de dos santos universales, Santo Domingo de Guzmán, fundador de la Orden de Predicadores o Dominicos, y San Telmo, dominico a su vez, Patrón de los Marinos.

Domingo de Guzmán y Garcés había nacido en Caleruega, en la comarca de la Ribera del Duero burgalesa. Su padre, Don Félix Núñez de Guzmán encomendó su educación a la familia materna, dejando a su hijo Domingo al cuidado del tío, Don Gonzalo de Aza, arcipreste de Gumiel de Izán, desde los siete a los catorce años. Previamente fue instruído en la piedad por la madre, Doña Juana Garcés, beatificada en 1828. Por cierto que su hermano Manés es también uno de los primeros beatos dominicos.

Domingo de Guzmán vivió en Palencia de los 14 a los 28 años, entre el año 1184 y el 1198. Estudió en su Studium Generale seis años de Filosofía y Humanidades y cuatro de Teología. Culminados sus estudios, en 1194 se ordenó sacerdote, al propio tiempo que fue nombrado Regente de la Cátedra de Sagradas Escrituras del Estudio palentino, ejerciendo como profesor durante cuatro años. En este tiempo fue designado también Vicario General de la diócesis.

En 1205 acompañó al Obispo de Osma, monseñor Diego de Acevedo, como embajador especial del rey Alfonso VIII a Dinamarca, para concertar con aquella Corte la boda del príncipe Don Fernando. Al regreso aprovechó para viajar a Roma, recibiendo el encargo del Papa Inocencio III ,en 1206, de trasladarse a Languedoc para tratar de convertir a los cátaros, como predicador. Ese mismo año fundó la primera casa femenina de su futura Orden, en Prouille. La primera masculina la fundó en Toulouse en 1215.

En Septiembre de 1215 regresó a Roma para acudir al Concilio de Letrán, viaje que aprovechó para solicitar el reconocimiento pontificio de la Orden de Predicadores. En tal intención regresó al año siguiente a Roma con un proyecto de Constituciones de la Orden, y el 22 de diciembre de ese año, de 1216, el Papa Honorio III libra la bula «Religiosam Vitam», que confirma la Orden de Predicadores.

El primer Capítulo General de los dominicos se celebró en Bolonia, en la fiesta de Pentecostés del año de 1220. Al año siguiente, el 6 de agosto, a la edad de 51 años, falleció Domingo de Guzmán en el convento de Bolonia, donde está su sepultura. Muy pronto, en 1234, Gregorio IX le canonizó, declarándose su festividad el 8 de agosto.

Por su parte, San Telmo fue en vida Pedro González Telmo, nacido en Astorga, sobre el año de 1190. Fue enviado por sus padres al cui- 
dado del Obispo Arderico, su tío, que le procuró la mejor instrucción hasta su admisión en el Estudio General de Palencia, donde cursó Física, Metafísica, Ciencias y, por supuesto, Teología.

Ordenado sacerdote por su tío Arderico, ejerció de canónigo de la Catedral. El Papa Honorio III le nombró deán de Palencia, contándose que investido como tal y a caballo cayó de bruces a un lodazal, lo que le hizo reflexionar sobre la ridiculez de las vanidades del mundo. Como cura de humildad ingresó en los dominicos de Palencia, bajo los votos de pobreza y obediencia.

Como predicador recorrió Navarra, Aragón, Cataluña, Valencia y Mallorca. Fue posteriormente maestro espiritual en el hospital de Guimaraes, en Portugal, con lo que entró en contacto con los marineros y pescadores. Por sus conocidas virtudes el rey (San) Fernando II lo llamó a la Corte como confesor y consejero, y en esa condición acompañó a los ejércitos a las tomas de Córdoba y Sevilla, predicando a las tropas y rezando por la victoria cristiana. En agradecimiento a la ayuda divina, al liberar Sevilla, las fuerzas cristianas entraron en la ciudad con la imagen de la Virgen de los Reyes, quedando en la ciudad gran veneración por San Telmo.

Renunciando al favor real, volvió al norte de Portugal y a Galicia, para facilitar el auxilio espiritual a los marineros, falleciendo en esa labor en Tuy, el 15 de abril de 1246, en cuya Catedral está enterrado, en la llamada Capela das Reliquias. Por su labor con los marinos y pescadores fue nombrado Patrón de los Navegantes. 
